\title{
What drives the dominance and distribution of Cyanobacteria and Dinoflagellata in reservoirs of Sri Lanka?
}

\author{
P. A. A. P. K. Senanayake ${ }^{1,2}$, S. Kumburegama ${ }^{3}$, C. S. Wijesundara ${ }^{3}$ and S. K. Yatigammana ${ }^{3 *}$ \\ ${ }^{1}$ Medical Research Institute, Colombo 08, Sri Lanka. \\ ${ }^{2}$ Postgraduate Institute of Science, University of Peradeniya, Peradeniya, Sri Lanka. \\ ${ }^{3}$ Depatartment of Zoology, Faculty of Science, University of Peradeniya, Peradeniya, Sri Lanka.
}

*Correspondence (sudharma_y@yahoo.com)

http://orcid.org/0000-0001-6002-8855

Received: 23.06.2020 Revised: 04.09.2020 Accepted: 13.09.2020 Published online: 15.03.2021

\begin{abstract}
Frequent records and health concerns in recent times have directed more attention on freshwater cyanobacterial and dinoflagellate blooms in Sri Lanka. Physico-chemical factors influencing phytoplankton growth are still under debate. This necessitates understanding environmental trends governing the dominance and distribution of algal blooms. Hence this study aimed to assess the dominance of Cyanobacteria and Dinoflagellata in reservoirs of Sri Lanka covering the three major climatic regions of the country, the Wet, Intermediate and Dry Zones. Plankton samples were collected using open type $20 \mu \mathrm{m}$ plankton net and identified using standard phytoplankton keys. Ninety-one species belonging to three phyla of phytoplankton were identified. Phylum Chlorophyta represented the highest species number followed by Bacillariophyta and Cyanophyta. Fourteen genera of Cyanobacteria were recorded and eleven of them were potentially toxigenic. The widest distribution was shown by Chroococcus and Merismopedia. Cylindrospermopsis raciborskii with the highest mean relative abundance was recorded in Intermediate and Dry Zone reservoirs. Peridinium aciculiferum was the only dinoflagellate species recorded during the study with the highest abundance in the Isinbessagala rocky pond. Except sixteen reservoirs which were mesoeutrophic, all the other studied reservoirs were found to be either eutrophic or hypereutrophic. Iranamadu tank recorded the highest TP concentration $\left(236 \mu \mathrm{g} \mathrm{L}^{-1}\right)$ value. $\mathrm{NO}_{3}^{-}$: TP ratio revealed the phosphate limited conditions in Wet and Dry Zone reservoirs whereas $\mathrm{N}$ was a limited factor in Intermediate Zone. Canonical Correspondence Analysis (CCA) results revealed that Secchi depth and area of water spread are important in determining both site and species variations in reservoirs of Sri Lanka.
\end{abstract}

Keywords: Cyanobacteria, Dinoflagellata, Environmental trends, Reservoirs, Physico-chemical factors

\section{INTRODUCTION}

Cyanobacteria are found in a range of habitats throughout the world. Increase of toxic and harmful cyanobacterial blooms especially in surface freshwaters necessitate studies focused on identification of supporting environmental conditions. Such studies help control harmful blooms through the application of proper mitigating measures. Moreover, cyanobacteria dominance due to cultural eutrophication has become a major environmental problem which ultimately challenges human health (Pathmalal 2009; Sethunga and Pathmalal 2010). Permanent cyanobacterial dominance is considered as the eventual phase of eutrophication occurring world-wide (Robarts 1985; Jones 1994; Pizzolon et al. 1999; Indika and Pathmalal 2014). Regardless of considerable research summarized in Schreurs (1992), Manage et al. $(1999 ; 2000 ; 2001)$, the reasons for such outbreaks largely remain unclear. Although it is clear that the increased input of nutrients is the major cause of the heavy selective pressure on the phytoplankton, it is the system as a whole which determines the final result of this process (Smith et al. 1987; Nakano et al. 1998; Nakano et al. 2001; Pathmalal et al. 2002; Yuichiro et al. 2004). A widely accepted concept is that blue-greens become dominant when the N:P ratio is low (Schindler 1977; Smith 1983 Nishii et al. 2001). However, the real scenario behind the cyanobacterial dominance is still controversial (Giaramida et al. 2013). Some prokaryotic properties of cyanobacteria such as gasvesicles, low $\mathrm{CO}_{2} /$ high $\mathrm{pH}$ optimum and nitrogenfixation are of special ecological significance (Schreurs 1992; Mur et al. 1993; Bryant 1994; Pathmalal and Premetilake 2011). Besides nutrients, the morphology of lakes is also of vital importance for cyanobacterial development. According to Schreurs (1992), long-term dominance by 


\section{P.A.A.P.K. Senanayake et al}

filamentous cyanobacterial species is related to shallow lake depth while colony forming species are more commonly dominant in deeper lakes. It has been suggested that increasing temperatures would also benefit Cyanobacteria, both directly and indirectly via increased thermal stratification (Paerl and Huisman 2008; Sethunga and Pathmalal 2010).

Dinoflagellates on the other hand are unicellular protists that frequently develop intense blooms in marine environments as well as in freshwater lakes or reservoirs. Common bloom-forming genera in freshwaters are Ceratium, Peridinium and Peridiniopsis while Peridinium polonicum, $P$. willei, $P$. volzii and $P$. aciculiferum have been identified as toxic dinoflagellates that are common in freshwaters (Niese et al. 2007). A number of studies have been carried out on the environmental factors that regulate the development of such blooms (Pollingher and Serruya 1976; Pollingher 1988; Lindström 1992; Olrik 1992). A range of environmental factors associated with the development of dinoflagellates in aquatic environments have been well documented (Horne et al. 1971; Herrgesell et al. 1976; Watanabe and Shiraishi 1983; Watanabe and Takada 1983; Lindström 1992). Among those, wind, radiation, water temperature, and precipitation are the most important physical factors that influence the distribution of dinoflagellates. However, the dominant species of dianoflagellates in the environment are determined by the combination of existing environmental conditions (Bruno and McLaughlin 1977; Holt and Pfiester 1981).

Sri Lanka is a tropical continental island located between latitudes $5^{\circ} 55^{\prime} \mathrm{N}$ and $9^{\circ} 50^{\prime} \mathrm{N}$ and longitudes $79^{\circ} 42^{\prime} \mathrm{E}$ and $81^{\circ} 52^{\prime} \mathrm{E}$. Its landscape is greatly influenced by an intense network of freshwater bodies which comprises of 103 rivers, and more importantly, about ten thousand operational freshwater reservoirs. About 40 species of Cyanobacteria belonging to 24 genera have been reported to date from reservoirs of Sri Lanka (Pathmalal and Piyasiri 1995; Sethunga and Pathmalal 2010). Of these, except Microcystis aeruginosa, the other species are either rare or occur in small numbers (Silva and Wijeyaratne 1999). Concerns about cyanobacterial blooms in freshwaters of Sri Lanka have increased in recent years due to frequent recordings of cyanobacterial blooms, problems created by blooms formed in aesthetic water bodies, records of toxic blooms and suspected fish kills by cyanobacterial blooms (Codd 1996; Anon. 1998; Jayatissa et al. 1998; Silva and Wijeyaratne 1999; Silva and Schiemer 2001; Pathmalal et al. 2009, 2010). In addition, a patchy distribution of thick cyanobacterial scum in irrigation water bodies in Sri Lanka is commonly observed, particularly in the dry season (Silva and Wijeyaratne 1999; Silva and Gamlath 2000; Sethunga and Manage 2010; Yatigammana and Perera 2017). Moreover, the dinoflagellate $P$. aciculiferum has been recorded from Sri Lankan drinking water reservoirs (Yatigammana et al. 2011).

During the recent past, focus has been directed on factors influencing the growth of phytoplankton communities mainly in relation to physico-chemical factors (Akbay et al. 1999; Peerapornpisal et al. 1999; Elliott et al. 2002). Conversely a preliminary study carried out on 45 Sri Lankan reservoirs revealed that the temperature is the most important environmental variable that determines the species variation of phytoplankton among the sites (Senanayake and Yatigammana 2017). Further extensive studies to assess especially the dominance of cyanobacteria and dinoflagellata in Sri Lankan reservoirs with respect to environmental variables are essential. Hence, the present study was designed to assess the abundance, dominance and potential environmental factors that determine the distribution of cyanobacteria and dinoflagellates in reservoirs of Sri Lanka including the areas that were affected by the civil war in the island.

\section{MATERIALS AND METHODS}

\section{Study sites}

Study sites were selected considering the age of reservoirs, climatic region, catchment characteristics, morphometry, biological composition and known algal outbreaks within the recent five years. One hundred and twelve (112) reservoirs from the three major climatic regions of Sri Lanka (Wet, Intermediate and Dry Zone) were selected. This included fourteen (14) reservoirs from the Wet Zone (WZ), twenty (20) from the Intermediate Zone (IZ) and seventy-eight (78) from the Dry Zone (DZ) (Figure 1). 


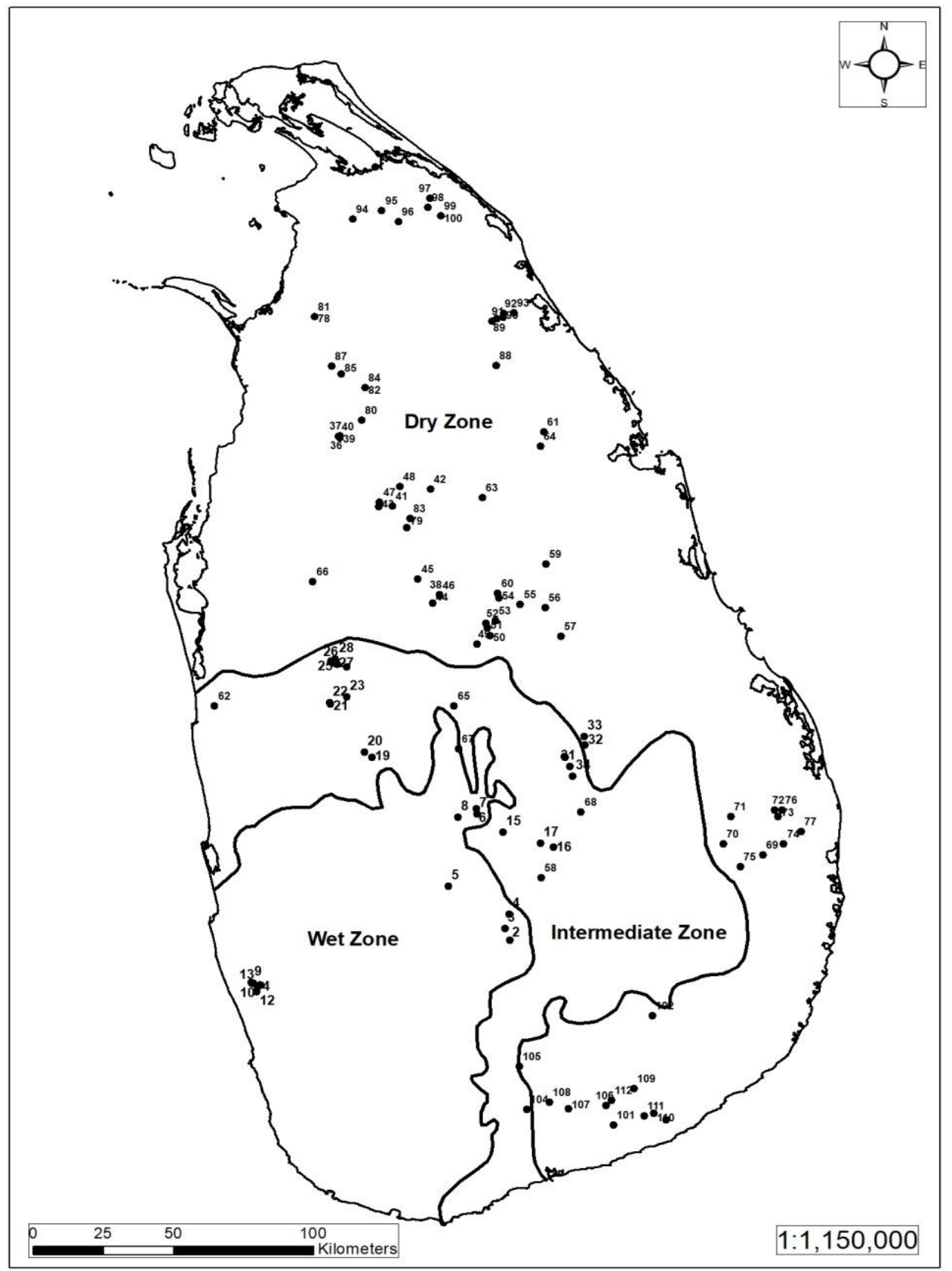

Fig 1 Locations of the 112 study reservoirs in Sri Lanka. The country is divided into three main climatic regions: Dry Zone, Intermediate Zone and Wet Zone.

1-Gregory, 2-Ambewela, 3-Kande ela, 4Bomburuella, 5- Kothmale, 6-Walala 7Dambarawa, 8- Kandy ,9-Aluthgama, 10Gammanpila, 11- Uyanwatta, 12- Wavita 13Veedagama,14- Kudu wewa, 15- Victoria, 16- Rantambe, 17- Randenigala,18Narangamuwa, 19- Kurunegala tank, 20Saragama, 21- Mangulagama small tank, 22Mangulagama large tank, 23-Daduruoya reservoir, 24- Balalla, 25- mbulgodayagama, 26- Vilawa, 27- Thammitagama wewa, 28Maningamuwa pahala, 29- Attanapola, 30Ginnoruwa, 31- Girandurukotte, 32Diyawiddagama, 33- Nawamedagama, 34Ballawiddawewa, 35- Isinbessagala pond 1, 36- Thanthirimale pond 1, 37- Isinbessagala wewa, 38- Isinbessagala pond 2, 39Thanthirimale pond 2, 40- Arahathgala cave, 41- Nuwara wewa, 42- Mahakanadarawa, 43Tisa wewa, 44- Kala wewa, 45Ganthiriyagama, 46- Nikiniyagala, 47Abhaya wewa, 48- Maankadawala, 49Kandalama, 50- Lenawa aluth wewa, 51Kimbissa egoda wewa, 52- Kaayanwala, 53Sigiriya, 54- Moragaswewa, 55- Minneriya, 56- Giritale, 57- Parakrama Samudraya, 58Divulankadawala, 59- Kaudulla, 60Alapathte wewa, 61- Mahaelagamuwa,

62- Kelegama, 63- Thuruwila, 64- Punchikulama, 65- Nalanda, 66- Mawatha wewa, 67- Wettankulama, 68- Dambarawa (Mahiyanganaya), 69- Ekgaloya, 70Senanayake Samudra, 71- Namaloya, 72- Karangawa, 73- Ampara, 74- Malayadi, 75- Jayanthi wewa, 76- Raja wewa, 77- Irakkamam, 78- Periyamadu, 79Nachchaduwa, 80- Mudaliyarkulam, 81- Thachchana marandamadu, 82- Mohandankulam, 83- Kawarakkulam, 84- Giants tank, 85- Periyathampanai, 86Andiyapuliyankulam, 87- Periyapandivirichchan, 88- Padaviya, 89- Nika wewa, 90- Sampathnuwara wewa, 91- Etha wetunu wewa, 92- Ahetu wewa, 93Kiriibbanwewa, 94- Iyarkulam, 95- Kanakambikaikulam, 96- Iranamadu, 97- Addaikulam, 98- Vishwamadu, 99- Udayarkattukulam, 100- Tissa, 101- Bandagiriya, 102- Gonagalara, 103- Yoda wewa, 104- Chandrika wewa, 105- Udawalawe, 106- Pahalamattala, 107- Sooriya wewa, 108- Sevanagala, 109- Lunugamvehera, 110- Debara wewa, 111- Weerawila, 112- Udamattala 


\section{P.A.A.P.K. Senanayake et al}

\section{Sample collection}

Sampling for both biological and limnological analysis were done from July 2015 to December 2017. Water samples were collected from $0.3 \mathrm{~m}$ below the air-water interface close to the centre for the chemical analysis while sub surface water samples $(\sim 0.5 \mathrm{~m})$ were collected for the biological analysis. Phytoplankton samples were collected from at least five sites from each reservoir along the banks and near the center to attain the best representation following standard sampling procedures (Cavanagh et al. 1997). Plankton net with a pore size of $20 \mu \mathrm{m}$ was used for the sampling. Acid washed clean plastic containers of $200 \mathrm{ml}$ capacity were used for sample storage. Phytoplankton was immediately preserved using acidified Lugol's iodine solution at a final concentration of $1 \%$ transported in dark condition and kept at $4^{\circ} \mathrm{C}$ until analysis (Idroos et al. 2014).

\section{Biological data analysis}

Taxonomic analysis of the preserved phytoplankton was done as early as possible with a maximum delay time of 48 hours. Samples were observed using an Olympus CX 31 research light microscope equipped with phase contrast optics. The species were identified to the lowest possible taxonomic level using standard identification guides (Abeywickrama 1979; Bellinger and Sigee 2010). The following equation was used to calculate the relative abundance (RA) of each identified taxon.

$$
\mathrm{RA}=\frac{\mathrm{n}_{\mathrm{i}}}{\mathrm{N}} \times 100
$$

where, $n_{i}$ is the number of individuals of a particular species, and $\mathrm{N}$ is the total number of individuals

\section{Environmental data analysis}

Total of thirteen environmental variables were measured. Field instruments, laboratory analysis and published secondary data were used for understanding of environmental conditions of the studied reservoirs. Conductivity, salinity and total dissolved solids (TDS) were measured where the samples were taken for the biological analysis. A portable conductivity meter (HACH SenSION EC
5) was used to measure conductivity, TDS and salinity. $\mathrm{pH}$ and temperature were recorded using a portable pH meter (HANNA, HI 9124, HI 9125) and Secchi depth was taken using a Secchi disc with 20.0 $\mathrm{cm}$ diameter.

Sample collection, preservation and laboratory analysis were done according to American Public Health Association (APHA) standard methods for examination of water and waste water (APHA 1992). Laboratory analysis of alkalinity, nitrate-N and total phosphorus (TP) were done using standard titrimetric methods.

\section{Statistical analysis}

Multivariate statistical analysis was used to identify the relationship between environmental factors [total phosphorus (TP), Nitrate-N, alkalinity, salinity, conductivity, total dissolved solids (TDS), temperature, dissolved oxygen, Secchi depth, $\mathrm{pH}$, lake area, catchment area and age], cyanobacteria and dianoflagellate composition. Canonical Correspondence Analysis (CCA) was used to understand the environmental variable(s) that could best explain the distribution of Cyanobacteria and Dinoflagellata species in the study sites using the statistical software, Canoco for windows (v.5).

\section{RESULTS}

Species composition, Distribution and Relative abundance of Cyanobacteria and Dinoflagellata

The relative abundance and distribution of phytoplankton community in different climatic regions showed a clear variation during the study. There were 91 species identified under the nine phyla of phytoplankton with the largest number of species belonging to Phylum Chlorophyta followed by the phyla Bacillariophyta and Cyanophyta. Species belonging to Euglenophyta, Charophyta, Ochrophyta, Stretophyta and Pyrrophyta (Dinoflagellata) were not major contributors to the total species richness. In terms of abundance, Aulacoseira granulata in the phylum Bacillariophyta dominated the phytoplankton community throughout the study in all climatic regions (Mean RA $=32.31 \%$ in WZ, 27.14\% in IZ and $33.24 \%$ in DZ) (Figure 2). 


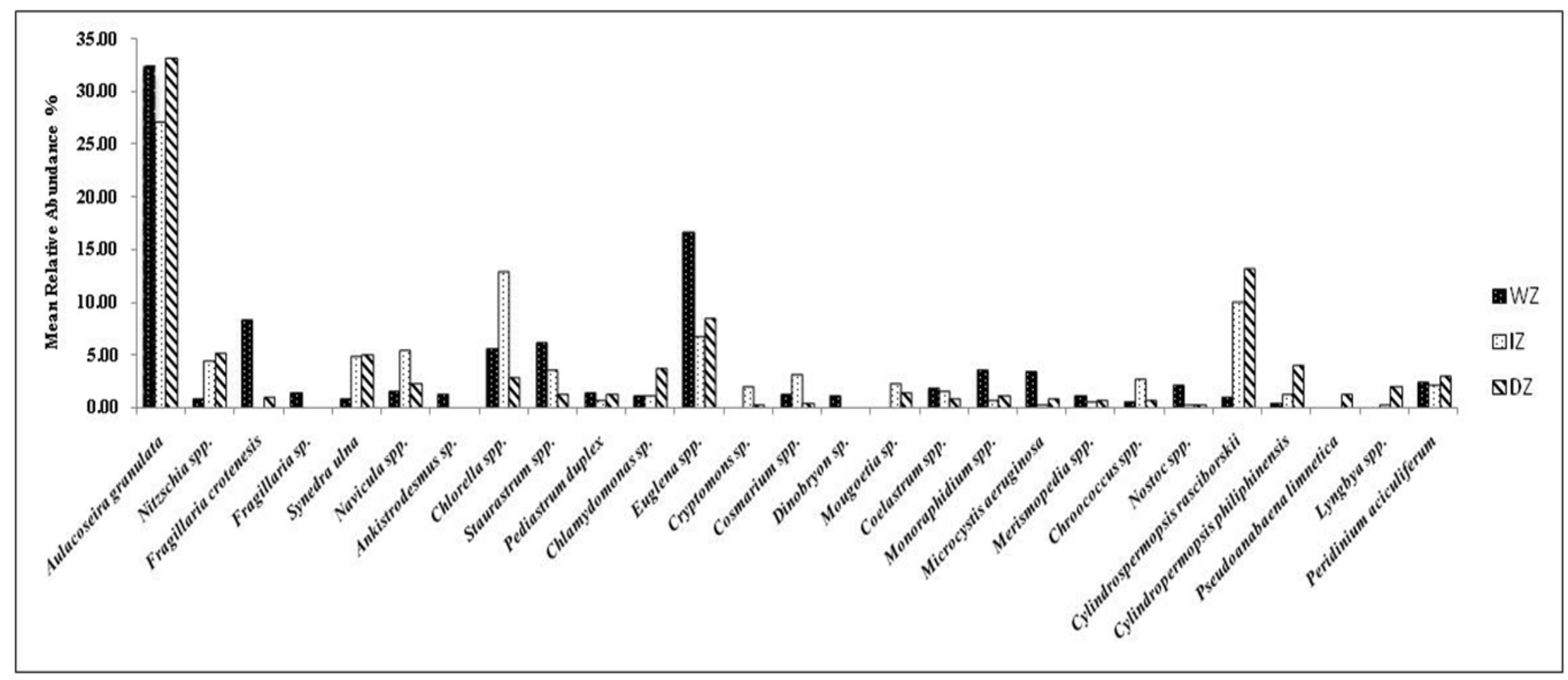

Fig 2 Comparison of mean relative abundances of the most abundant phytoplankton species in different climatic regions $($ WZ $=$ wet Zone, IZ = Intermediate Zone, DZ = Dry Zone) 


\section{P.A.A.P.K. Senanayake et al}

More than $50 \%$ relative abundance of this species was recorded in $21 \%$ of the Wet Zone reservoirs, $30 \%$ of the Intermediate Zone and $33.33 \%$ of the Dry Zone reservoirs respectively. Interestingly, Aulacoseira granulata dominated all the studied reservoirs of the Mahaweli Development Programme which lie in Wet and Intermediate Zones. In addition, Euglena spp. was the second most abundant species in the Wet Zone. Further, Chlorella spp. was the second most abundant species in the Intermediate Zone while Cylindrospermopsis raciborskii showed a relatively high abundance in both Intermediate and Dry Zone reservoirs (Figure 2).
Microcystis aeruginosa

Nostoc spp.

Cylindrospermopsisraciborskii

Chroococcus spp.

Merismopedia spp.

Oscillatoria spp.

Pseudoanabaenalimnetica

Anabaena spp.

Lyngbya spp.

Coelaspharium sp.

Aphanocapsa sp.

Spirulina spp.

Aphanothece sp.

Cylindromopsis phillippinensis
Mean Relative Abundance (\%)

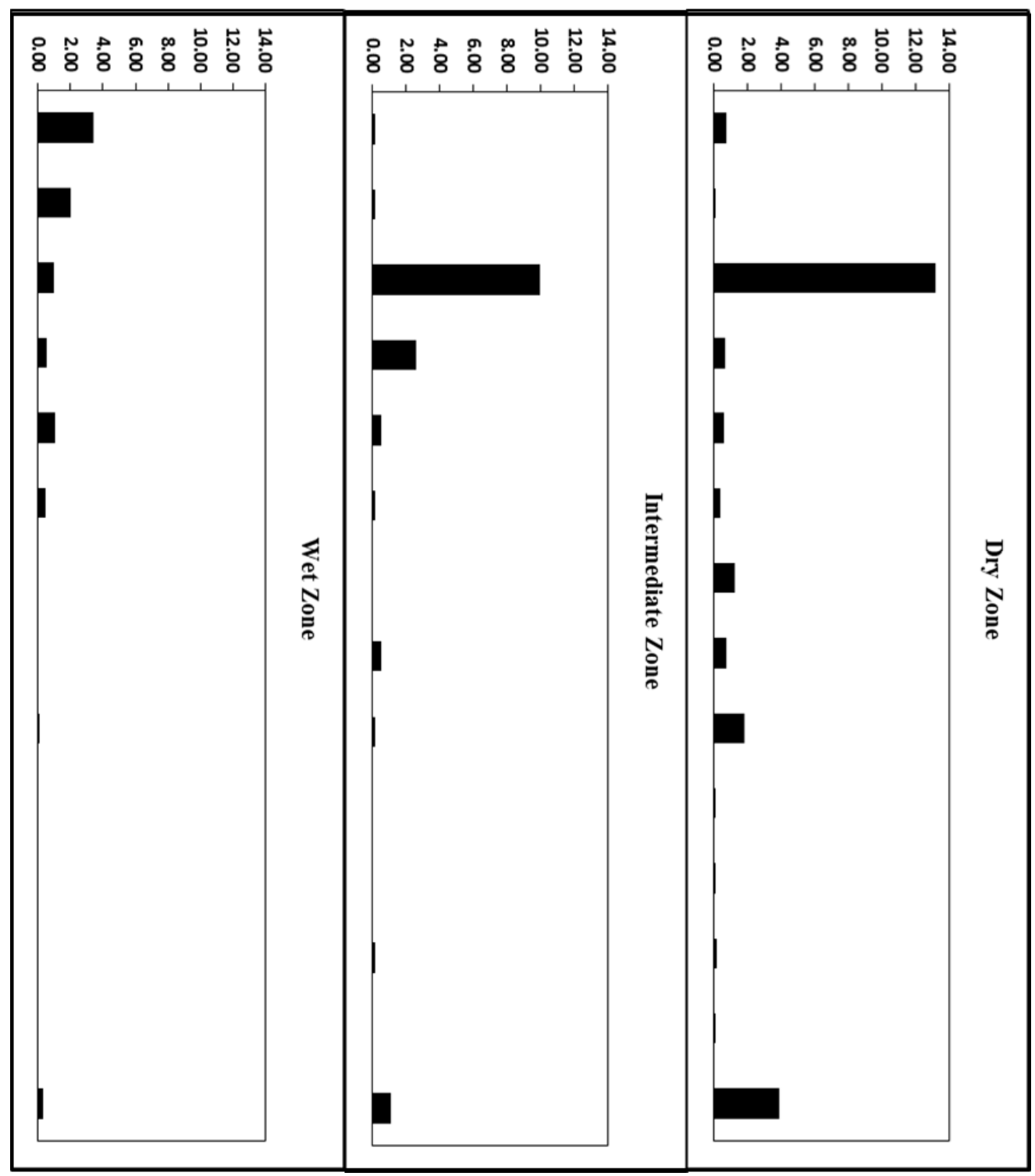

Fig 3 Comparison of mean relative abundances of cyanobacterial species in different climatic regions 
Fourteen genera of Cyanobacteria recorded during the study include M. aeruginosa, Nostoc spp., $\quad$ C. raciborskii, Oscillatoria spp., Pseudoanabaena limnetica, Anabaena spp., Lyngbya spp., Coelosphaerium sp., Aphanocapsa sp., Aphanothece sp., Cylindrospermopsis philippinensis, Chroococcus spp., Merismopoedia spp., Spirulina spp., and of these the first eleven are potentially toxigenic (Figure 3). Among the recorded species $M$. aeruginosa, $C$. raciborskii and C. philippinensis were widely distributed cyanobacterial species in Sri Lankan reservoirs. $M$. aeruginosa was the major cyanobacterial species in the Wet Zone (Figure 3) and the highest population was recorded in the Kandeela reservoir (RA = $37.5 \%$ ). However, Vishwamadu reservoir in the Dry Zone also showed a notable incidence of $M$. aeruginosa with a relative abundance of $22.22 \%$. The relative importance of $C$. philippinensis in the phytoplankton assemblage was found to be high (RA $\geq 25 \%$ ) in five study reservoirs in the Dry Zone (Ekgaloya, Periyapandiviruchchan, Kanakambikaikulam, Ahetuwewa and Udayarkattukulam). Relative abundance of $C$. raciborskii ranged from

Table 1 Occurrence of Cyanobacteria and Dinoflagellata in study reservoirs

\begin{tabular}{lc}
\hline Species & $\begin{array}{c}\text { Occurrence } \\
\text { in No. of } \\
\text { reservoirs }\end{array}$ \\
\hline \hline Chroococcus spp. & 54 \\
Merismopedia spp. & 41 \\
Lyngbya spp. & 37 \\
Microcystisaeruginosa & 36 \\
Cylindrospermopsisrasciborskii & 35 \\
Oscillatoria spp. & 34 \\
Anabaena spp. & 29 \\
Cylindropermopsisphilippinensis & 19 \\
Nostoc spp. & 9 \\
Spirulina spp. & 9 \\
Pseudoanabaenalimnetica & 5 \\
Coelosphaerium sp. & 2 \\
Aphanocapsa sp. & 1 \\
Aphanothece sp. & 1 \\
Peridiniumaciculiferum & 36 \\
\hline
\end{tabular}

$0.28 \%$ (Nawamedagama reservoir) to $97.27 \%$ (Kurunegala Lake) while dominating $31.25 \%$ of the study reservoirs with $>50 \%$ relative abundance. These include 13 reservoirs of the Dry Zone (Nuwarawewa, Tisa wewa, Kandalama, Moragaswewa, Minneriya, Giritale, Parakramasamudra, Kaudulla, Thuruwila, Ampara tank, Iaranamadu, Udayrkattukulam and Sooriyawewa) and two reservoirs of the Intermediate Zone (Kurunegala Lake and Ballawiddawewa). Furthermore, C. raciborskii had the highest mean relative abundance in both Intermediate and Dry Zone than any of the other cyanobacterial species (Figure 3). However, this species was not dominant in reservoirs in the Wet Zone.

However, it is evident that non-toxigenic cyanobacterial genera, Chroococcus and Merismopedia had the highest distribution occurring in 54 and 41 of the study reservoirs respectively. But, the relative abundance of these two species was very low (Table 1). Our study shows that Dry Zone reservoirs contain more cyanobacterial species compared to those in the other two climatic regions (Figure 3).

Peridinium aciculiferum was the only dinoflagellate species that was found during this study and its highest abundance $(\mathrm{RA}=98.92 \%)$ was recorded in the Isinbessagala rocky pond in Medawachchiya area. However, Dambarawa lake in the Wet Zone, Abhayawewa and Divulankadawala reservoirs in the Dry Zone showed moderate population levels of this species $(\mathrm{RA}>25 \%)$ in their phytoplankton assemblages.

\section{Physico-chemical factors of study reservoirs}

The minimum, maximum, median and mean values of thirteen physico-chemical variables measured in 112 reservoirs between July 2015 to December 2017 are listed in Table 2. The studied reservoirs (restored ancient irrigation tanks, tanks and reservoirs built during the recent past and hydropower and irrigation reservoirs built recently under River Development Projects) had a range of different morphological characteristics with the area ranging between 0.01$77.7 \mathrm{~km}^{2}$ and catchment size ranging between $0.01-$ $2332 \mathrm{~km}^{2}$. Except for 16 reservoirs which fall into the mesoeutrophic category $\left(\mathrm{TP}<30 \mu \mathrm{g} \mathrm{L}^{-1}\right)$ all the other reservoirs belonged to the eutrophic or hypereutrophic category $\left(\mathrm{TP} \geq 30 \mu \mathrm{g} \mathrm{L}^{-1}, \mathrm{TP} \geq 100\right.$ $\mu \mathrm{g} \mathrm{L}^{-1}$ ) (Table 3). Interestingly Iranamadu tank that 
was severely affected by the long civil war in the country recorded the highest TP value $\left(236 \mu \mathrm{g} \mathrm{L}^{-1}\right)$. The mean ratio between the nitrate- $\mathrm{N}$ and $\mathrm{TP}$ revealed that the Wet Zone and Dry Zone reservoirs have $\mathrm{P}$ limited conditions $\left(\mathrm{NO}_{3}^{-}: \mathrm{TP}>16\right)$. Conversely Intermediate Zone reservoirs showed N limited conditions $\left(\mathrm{NO}_{3}{ }^{-}\right.$: $\left.\mathrm{TP}<16\right)$. Values of the conductivity varied greatly among different climatic regions ranging from $16 \mu \mathrm{Scm}^{-1}$ to $1148 \mu \mathrm{Scm}^{-1}$ and the mean value ranged from $63.8 \mu \mathrm{Scm}^{-1}$ in the Wet Zone to $313.8 \mu \mathrm{Scm}^{-1}$ in the Dry Zone. $\mathrm{pH}$ values ranged from 6.31 to 9.7 while mean values ranged from 7.15 in the Wet Zone to 7.83 in the Dry Zone.
Wet Zone reservoirs showed the highest mean value of nitrate- $\mathrm{N}(1.45 \mathrm{mg} / \mathrm{L})$ while Intermediate and Dry Zone showed relatively lower values $(0.61 \mathrm{mg} / \mathrm{L}$ and $0.82 \mathrm{mg} / \mathrm{L}$ respectively) (Table 3). Average temperature of the study reservoirs ranged from $27.64{ }^{\circ} \mathrm{C}$ (Wet Zone) to $30.14{ }^{\circ} \mathrm{C}$ (Dry Zone). The Dissolved oxygen level averaged from $6.15 \mathrm{mg} / \mathrm{L}$ in the Wet Zone to $6.44 \mathrm{mg} / \mathrm{L}$ in the Dry Zone. TDS values presented a well-marked variation among the different climatic regions ranging from $33 \mathrm{mg} / \mathrm{L}$ to $546 \mathrm{mg} / \mathrm{L}$ (Table 3). 
P.A.A.P.K. Senanayake et al

Table 2 Minimum, maximum, mean and median of Environmental data of the 112 study sites (Abbreviations: TP = Total Phosphorus; TDS = Total Dissolved Solids; DO = Dissolved Oxygen)

\begin{tabular}{|c|c|c|c|c|c|c|c|c|c|c|c|c|}
\hline & \multicolumn{3}{|c|}{ Max } & \multicolumn{3}{|c|}{ Min } & \multicolumn{3}{|c|}{ Median } & \multicolumn{3}{|c|}{ Mean } \\
\hline & $\mathbf{W Z}$ & IZ & DZ & $\mathbf{W Z}$ & IZ & DZ & $\mathbf{W Z}$ & IZ & DZ & $\mathbf{W Z}$ & IZ & DZ \\
\hline Catchment $\left(\mathrm{km}^{2}\right)$ & 543.90 & 2332.29 & 994.50 & 0.10 & 0.60 & 0.01 & 0.99 & 1.54 & 19.02 & 41.56 & 338.81 & 87.24 \\
\hline Area $\left(\mathrm{km}^{2}\right)$ & 13.74 & 22.70 & 77.70 & 0.01 & 0.04 & 0.001 & 0.10 & 0.15 & 1.66 & 1.20 & 3.71 & 6.36 \\
\hline Age (yrs) & 205.00 & 143.00 & 143.00 & 30.00 & 5.00 & 31.00 & 78.00 & 65.00 & 63.50 & 83.00 & 56.6 & 73.14 \\
\hline $\mathrm{TP}\left(\mu \mathrm{g} \mathrm{L}^{-1}\right)$ & 160.00 & 160.00 & 236.00 & 22.00 & 11.00 & 10.00 & 44.50 & 41.00 & 90.00 & 56.00 & 51.90 & 88.40 \\
\hline $\mathrm{pH}$ & 7.85 & 8.87 & 9.70 & 6.46 & 6.31 & 6.72 & 7.17 & 7.48 & 7.82 & 7.15 & 7.60 & 7.83 \\
\hline Conductivity $\left(\mu \mathrm{S} \mathrm{cm}^{-1}\right)$ & 283.00 & 561.00 & 1148.00 & 16.31 & 89.20 & 61.00 & 73.5 & 167.50 & 311.00 & 106.44 & 256.78 & 364.86 \\
\hline Secchi Depth (m) & 1.53 & 1.65 & 2.00 & 0.10 & 0.19 & 0.01 & 0.77 & 1.00 & 0.61 & 0.81 & 0.90 & 0.59 \\
\hline Alkalinity (mg $\left.\mathrm{L}^{-1}\right)$ & 53.00 & 146.00 & 161.00 & 8.00 & 21.40 & 12.00 & 27.75 & 56.00 & 64.00 & 29.57 & 70.97 & 66.53 \\
\hline $\operatorname{TDS}\left(\mathrm{mg} \mathrm{\textrm {L } ^ { - 1 } )}\right.$ & 186.5 & 362.00 & 546.00 & 10.51 & 57.00 & 33.00 & 36.15 & 96.00 & 186.15 & 65.28 & 158.15 & 199.16 \\
\hline Temperature $\left({ }^{\circ} \mathrm{C}\right)$ & 32.00 & 34.00 & 34.20 & 21.00 & 25.00 & 26.00 & 29.95 & 29.25 & 30.00 & 27.64 & 29.21 & 30.14 \\
\hline Salinity (ppt) & 0.27 & 0.27 & 0.47 & 0.01 & 0.04 & 0.03 & 0.03 & 0.07 & 0.13 & 0.06 & 0.12 & 0.15 \\
\hline $\mathrm{NO3}^{-}\left(\mathrm{mg} \mathrm{L}^{-1}\right)$ & 3.20 & 2.00 & 3.10 & 0.30 & 0.30 & 0.20 & 1.35 & 0.55 & 0.65 & 1.45 & 0.61 & 0.82 \\
\hline $\mathrm{DO}\left(\mathrm{mg} \mathrm{L}^{-1}\right)$ & 7.50 & 8.50 & 12.69 & 4.70 & 3.36 & 2.06 & 6.17 & 6.35 & 6.49 & 6.15 & 5.7 & 6.44 \\
\hline $\mathrm{NO}_{3}{ }^{-}: \mathrm{TP}$ & 59.09 & 54.55 & 290.00 & 6.52 & 4.38 & 1.67 & 34.58 & 12.76 & 8.38 & 30.64 & 16.47 & 13.96 \\
\hline
\end{tabular}


Table 3: Trophic categorization of study reservoirs

\begin{tabular}{lcccc}
\hline & \multicolumn{3}{c}{ TP level $\left(\boldsymbol{\mu g} \mathbf{L}^{-1}\right)$} & Total \\
Climatic region & $<\mathbf{3 0}$ & $\mathbf{2} \mathbf{3 0}$ & $>\mathbf{1 0 0}$ & \\
\hline WZ & 1 & 12 & 1 & 14 \\
IZ & 8 & 9 & 3 & 20 \\
DZ & 7 & 44 & 27 & 78 \\
\hline Total & $\mathbf{1 6}$ & $\mathbf{6 5}$ & $\mathbf{3 1}$ & $\mathbf{1 1 2}$ \\
\hline
\end{tabular}

Relationship between physico-chemical variables and Cyanobacteria and Dinoflagellata abundance

Canonical Correspondence Analysis (CCA) was carried out to understand the importance of the measured environmental variables in the species variation (Figures 4 and 5). The relative length of each vector (environmental variable) indicates the degree of importance of each environmental factor to determine the diversity and abundance of the species in different sites. The angle between the environmental variable and the respective axis indicates the correlation of each environmental variable with the environmental gradients of significance.

CCA results revealed that both sites and species variations are best explained by Secchi depth and area of water spread although temperature and nutrients such as total phosphorus and $\mathrm{NO}_{3}{ }^{-}$also appeared to be important explanatory factors (Figure 4 and 5). Further the CCA biplot (Figure 4 and 5) showed a strongly inter correlated group of factors describing lake water chemistry (alkalinity, salinity, TDS and conductivity) which was positively related to temperature, $\mathrm{pH}$, total phosphorus and $\mathrm{DO}$ of the reservoir and negatively to lake morphometry (catchment area, Area of water spread and Secchi depth). However, the correlation between $\mathrm{NO}_{3}{ }^{-}$and TP was negative. Most of the green algal taxa (Family Chlorophyceae) and some diatom species (Family Bacillariophyceae) appear to prefer relatively lower temperatures and $\mathrm{pH}$ (Figure 5). The distribution of species along the environmental gradients indicates toxigenic cyanobacteria: $M$. aeruginosa and Nostoc spp. are strongly associated with nitrate concentration. C.raciborskii as the dominant cyanobacterium throughout the study showed a better relationship with $\mathrm{pH}$ and temperature. Increase in conductivity and related variables were clearly preferred by Lyngbya spp. Furthermore, $C$. phillippinensis as a major constituent of phytoplankton assemblages in some dry zone reservoirs appeared to prefer clear water conditions (High Secchi depth). 


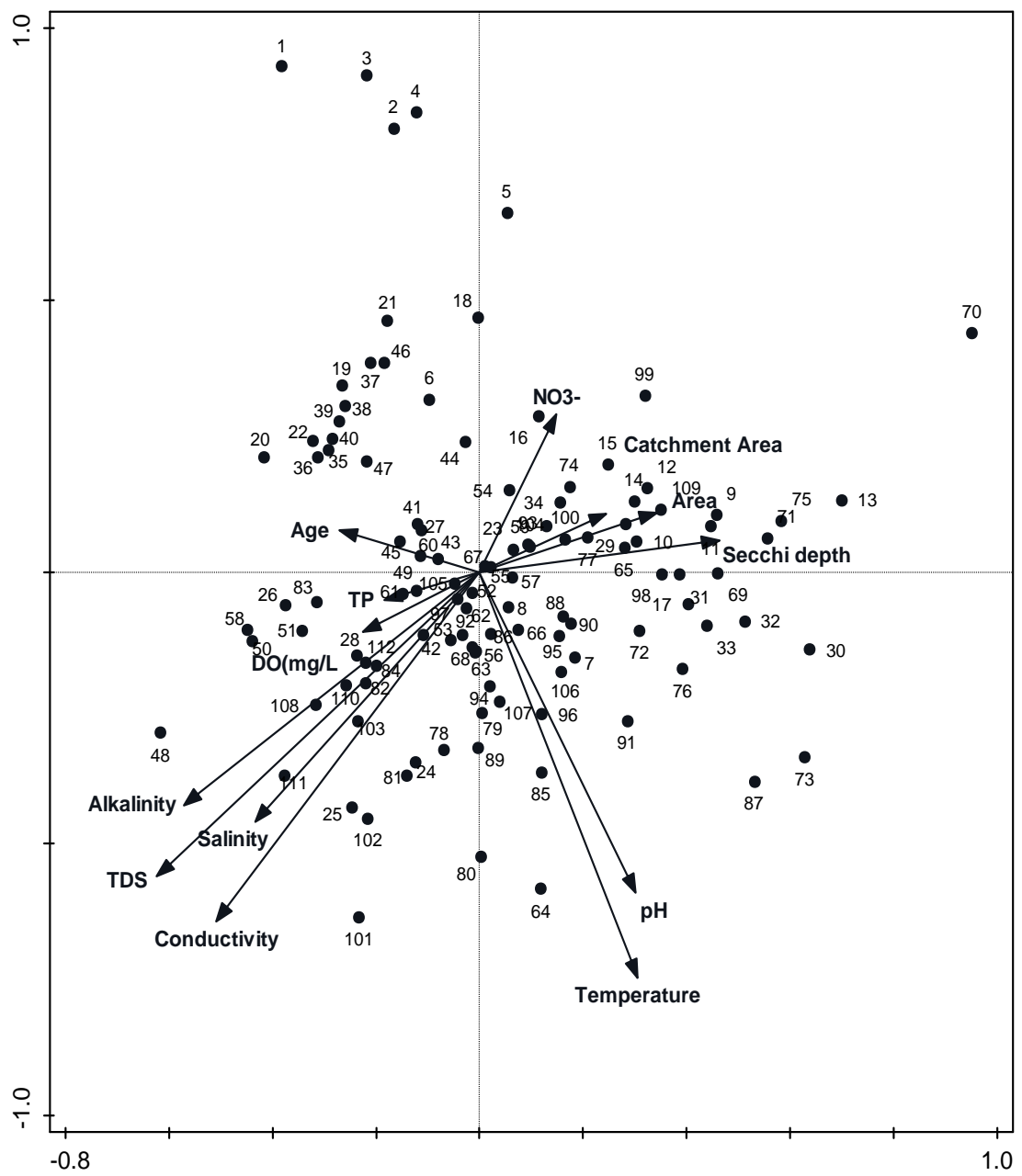

Fig 4 Canonical Correspondence Analysis (CCA) ordination diagram of sites with environmental variables. Solid arrows represent forward selected environmental variables and dashed arrows represent environmental variables that were plotted passively in the ordination. (TDS = Total Dissolved Solids, DO- Dissolved Oxygen)1-Gregory, 2-Ambewela, 3-Kande ela, 4Bomburuella, 5- Kothmale, 6-Walala,7- Dambarawa, 8- Kandy ,9-Aluthgama, 10- Gammanpila, 11- Uyanwatta, 12- Wavita, 13Veedagama,14- Kudu wewa, 15- Victoria, 16- Rantambe, 17- Randenigala,18- Narangamuwa, 19- Kurunegala tank,20Saragama, 21- Mangulagama small tank, 22- Mangulagama large tank, 23- Daduruoya reservoir, 24- Balalla, 25Imbulgodayagama,26- Vilawa, 27- Thammitagamawewa, 28- Maningamuwapahala, 29- Attanapola, 30- Ginnoruwa, 31Girandurukotte, 32- Diyawiddagama, 33- Nawamedagama, 34- Ballawiddawewa, 35- Isinbessagala pond 1, 36- Thanthirimale pond 1, 37- Isinbessagalawewa, 38- Isinbessagala pond 2, 39- Thanthirimale pond 2, 40- Arahathgala cave, 41- Nuwara wewa,42Mahakanadarawa,43- Tisa wewa, 44- Kala wewa, 45- Ganthiriyagama, 46- Nikiniyagala, 47- Abhayawewa, 48- Maankadawala, 49- Kandalama, 50- Lenawaaluthwewa, 51- Kimbissaegodawewa, 52- Kaayanwala, 53- Sigiriya, 54- Moragaswewa, 55Minneriya, 56- Giritale, 57- ParakramaSamudraya, 58- Divulankadawala, 59- Kaudulla, 60- Alapathtewewa, 61Mahaelagamuwa, 62- Kelegama, 63- Thuruwila, 64- Punchikulama, 65- Nalanda, 66- Mawathawewa, 67- Wettankulama, 68Dambarawa (Mahiyanganaya), 69- Ekgaloya, 70- Senanayakesamudraya, 71- Namaloya, 72- Karangawa, 73- Ampara, 74Malayadi, 75- Jayanthiwewa, 76- Raja wewa, 77- Irakkamam, 78- Periyamadu, 79- Nachchaduwa, 80- Mudaliyarkulam, 81Thachchanamarandamadu, 82- Mohandankulam, 83- Kawarakkulam, 84- Giants tank, 85- Periyathampanai, 86Andiyapuliyankulam, 87- Periyapandivirichchan, 88- Padaviya, 89- Nikawewa, 90- Sampathnuwarawewa, 91Ethawetunuwewa, 92- Ahetuwewa, 93- Kiriibbanwewa, 94- Iyarkulam, 95- Kanakambikaikulam, 96- Iranamadu, 97Addaikulam, 98- Vishwamadu, 99- Udayarkattukulam, 100- Tissa, 101- Bandagiriya, 102- Gonagalara, 103- Yoda wewa, 104Chandrika wewa, 105- Udawalawe, 106- Pahalamattala, 107- Sooriyawewa, 108- Sevanagala, 109- Lunugamvehera, 110Debarawewa, 111- Weeravila, 112- Udamattala 


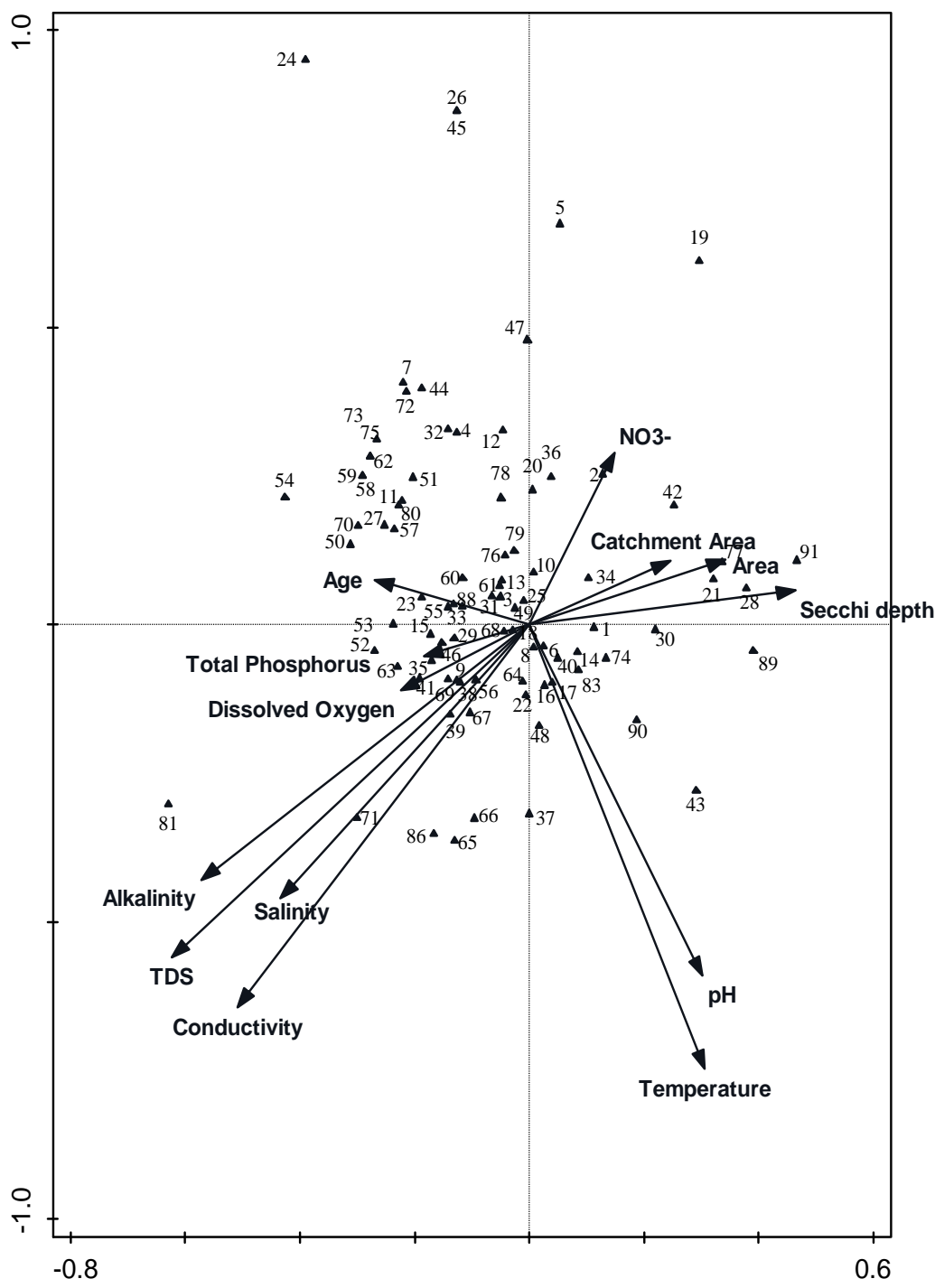

Fig 5 Canonical Correspondence Analysis (CCA) ordination diagram of species with environmental variables. Solid arrows represent forward selected environmental variables and dashed arrows represent environmental variables that were plotted passively in the ordination. (TDS = Total Dissolved Solids, DO- Dissolved Oxygen) 1-Aulacoseira sp., 2- Microcystis sp.3-Coelastrum spp., 4-Fragillariacrotenesis, 5- Fragillariacapucina, 6- Fragillariaspp., 7Scenedesmus abundance, 8- S. quadricauda, 9- S. arcuatus, 10- S. acuminatus, 11- S. dimorphus, 12- Nostocsp., 13Chlorella spp., 14-Cylindrospermopsisrasciborskii, 15- Mougoetiaspp., 16-Pediastrum simplex, 17- P. duplex, 18Chroococcusspp., 19-Sturastrum cingulum, 20- Staurastrummegacanthum, 21- Staurastrumspp., 22Merismopediaspp., 23-Oscillatoriaspp., 24-Tabellaria fenestrate, 25- Golenkiniaspp., 26-Ankistrodesmus convolutes, 27- A. falcatus, 28- Ankistrodesmusspp., 29-Navicula sp., 30- Cosmariumspp., 31Peridiniumaciculiferum, 32- Monorhaphidiumspp., 33-Closteriumspp., 34-Oocytisspp., 35-Cymbellaspp., 36Botryococcusspp., 37-Gyrosigmaspp., 38-Nitzschiaspp., 39-Pandorinaspp., 40- Euglena spp., 41Trachelomonasspp., 42-Pleudorinaspp., 43-Suriellalinearis, 44-Centric diatom 1, 45-Centric diatom 2, 46- Synedra ulna, 47- Diatom 1, 48- Pseudoanabaenalimnetica, 49- Chlamydomonasspp., 50-Gomphonemaspp., 51Cryptomonsspp., 52- Spirogyra spp., 53-Suriellaspp., 54-Oedogoniumspp., 55-Monoraphidiumcontortum, 56Anabaena spp., 57-Tetraedron minimum, 58- Tetrraedronlimneticum, 59- Tetrraedroncaudatum, 60Actinastrumspp., 61-Crucigeniatetrapedia, 62- Crucigeniaspp., 63-Pinnulariaspp., 64-Rhizosoleniaspp., 65Netriumspp., 66- Amphora spp., 67-Lyngbyaspp., 68-Phacusspp., 69-Haematococcussp., 70-Eudorina spp., 71Rhopalodiaspp., 72-Eunotiaspp., 73-Zygnemaspp., 74- Tetrads spp., 75-Ulothrixspp., 76-Selenastrumspp., 77Sorastrumspp., 78-Craticulaspp., 79-Coelosphaeriumsp., 80-Aphanocapsasp., 81-Oedogoniumsp., 82-Scenedesmus obliquus, 83- Spirulina spp., 84-Pediastrumobtusum, 85- Aphanothecesp., 86-Cyclotella sp., 87- Uroglina sp., 88Closteriopsis sp., 89-Cylindropermopsisphiliphinensis, 90- Scenedesmus sp., 91- Dinobryon sp. 


\section{DISCUSSION}

\section{Dominant taxa}

Generally, phytoplankton assemblages in tropical lakes are dominated by cosmopolitan taxa along with pan tropical taxa in lowland lakes (Vyverman 1996). Out of 4700 taxa recorded from Indo Malaysian and North Australian regions, majority are chlorophytes $(67 \%)$, especially desmids (57\%), diatoms (19\%) and blue green algae (6\%) and there is only a small number of phytoflagellates (Vyverman, 1996). This scenario clearly coincides with the results of the current study. Alkalinity and related variables (e.g., $\mathrm{pH}, \mathrm{TDS}$ ) are often found to be the most important variables influencing the distribution and the abundance of diatom taxa (Lotter et al. 1997; Weckström et al. 1997; Dixit et al. 1999; Sethunga and Pathmalal 2010). Dominance of alkaliphillous diatom, Aulacosera granulata in Sri Lankan reservoirs irrespective of the climatic region may be an indication of a particular geological substrate in the country that strongly influences the reservoirs water chemistry. For example, Laing and Smol (2003) demonstrated the importance of geological conditions in northern Russia where substrate-related changes in water chemistry overrode climatic gradients in explaining diatom distributions. On the other hand, Aulacosera granulata has also been classified as a eutrophic species (Reynolds 1984; Van Dam et al. 1994) and this may attribute to the wide distribution and dominance of this species in reservoirs of Sri Lanka that show more eutrophic conditions. Caraco and Miller (1998) and Huszar et al. (2003) reported high biomass of Fragillaria crotonensis at low water temperature and low electrolytic conductivity (Morabito et al. 2002). Hence, relatively low temperature and conductivity conditions in the Wet Zone reservoirs may support the enhanced growth of this species. It is well understood that the higher levels of carbon dioxide, nitrates and ammonia are found to be responsible for the luxuriant growth of Euglenaceae (Munnawar 1970, 1972). Elevated levels of nitrates recorded in the Wet Zone reservoirs might be more important in the growth of Euglena spp. compared to reservoirs in other climatic regions. Navicula species are known to occur in stirred up, inorganically turbid, shallow lakes and in streams (Padisáket al. 2009). Interestingly the dominance of $C$. raciborskii in Intermediate and Dry Zone reservoirs is widely cited as a response to global warming (Briand et al. 2004; Stüken et al. 2006; Sethunga and Pathmalal 2010). C. raciborskii is a general species in tropical and pantropical regions (Cronbergand Annadotter 2006). Furthermore, this species has rapidly dispersed all over the world from the tropics to temperate zones (Fabbro and Duivenvoorden 1996; Chapman and Schelske 1997; Lagos et al. 1999; Shafik et al. 2001; Briand et al. 2004; Valerio et al. 2005; Bouvy et al. 2006; Fastner et al. 2007; Moustaka-Gouni et al. 2009; Alster et al. 2010; Kokociñski et al. 2010; Moisander et al. 2012) except Antarctica. C. raciborskii prefers highly eutrophic waters, when water temperature is high and light conditions are poor (Moustaka-Gouni et al. 2006, 2009). However, it can also survive in water bodies with lower trophic status, owing to its effective storage capacity of phosphorus (Istvánovics et al. 2000).

Eighteen out of the 40 genera known to comprise toxigenic species have been identified in Sri Lankan waters (Abeywickrama 1979; Rott 1983; Rott and Lenzenweger 1994; Sethunga and Pathmalal 2010) and 11 of these toxigenic species were recorded in this study. The highest distribution and relative abundance of $M$. aeruginosa, $C$. raciborskiiand $C$. philippinensis over the other cyanobacterial species may be attributed to the higher water temperatures $\left(>20^{\circ} \mathrm{C}\right)(\mathrm{McQueen}$ and Lean 1987), stable water column and high TP conditions prevailing in majority of the Sri Lankan reservoirs. The widespread distribution of two cyanobacterial genera: Chroococcus spp. and Merismopedia spp. may be due to the low specificity for nutrients (Phillips et al. 2012).

The dominance of $C$. raciborskii in dry zone reservoirs while its maximum relative abundance recorded from Kurunegala Lake can be related to the wide physiological tolerance inherent to this species to succeed over the others as described above. However, lower abundance of this species in wet zone reservoirs may be because $\mathrm{NO}_{3}^{-}$enriched systems promote non-nitrogen fixing taxa over the nitrogen fixing taxa. Further the distribution of $C$. raciborskii is negatively correlated with conductivity level of the water (Kokocinski and Soininen 2012). Hence, lower conductivity levels of wet zone reservoirs may be attributed to the lower abundance of this species. Though the highest incidence of $M$. aeruginosa was recorded in wet zone reservoirs we found that it has a wide 
distribution in all the other climatic regions of Sri Lanka. This situation may be attributed to excess nutrients (Silva and Wijeyaratne 1999; Nishii et al. 2002; Perera et al. 2012), high temperature and a stable water column with little vertical mixing which was also found in some other regions of the world (Reynolds and Walsby 1975; Huisman et al. 2004; Visser and Both 2005). According to Wang et al. (2011) and Idroos and Pathmalal (2018), M. aeruginosa can be controlled only by the $\mathrm{pH}$ adjustment but not with nutrient variations. Since Sri Lankan water bodies are maintaining mostly a neutral $\mathrm{pH}$ condition, the natural control of the cyanobacterium cannot be expected.

According to William (1971) dinoflagellates can succeed in all aquatic environments. Two Peridinium species: P. cinctum (Perera and Piyasiri 1998; Pathmalal and Piyasiri 1995) and $P$. aciculiferum (Yatigammana et al. 2011) have been recorded from Sri Lankan reservoirs. The current study also recorded a Peridinium species morphologically similar to $P$. aciculiferum from 36 reservoirs located in all three climatic regions. Silva et al. (2013) have recorded that Peridinium was found in low abundances in some dry zone waters with low flushing rate and also with low $\mathrm{pH}$ values associated with dissolved organic acids such as humic and fulvic acids. In general, rocky ponds are stagnant water bodies having low or no flushing with high concentrations of dissolved organic matter. Therefore, this condition can be used to explain the maximum abundance $(98 \%)$ of $P$. aciculiferum in Isinbessagala rocky pond in Medawachchiya area where dissolved organic acid content is high.

\section{Limnological parameters}

According to trophic categorization, more than $75 \%$ of the study reservoirs irrespective of the climatic region come under eutrophic ( $\mathrm{TP}>30 \mu \mathrm{g} \mathrm{L}^{-1}$ ), or hypereutrophic (TP $>100 \mu \mathrm{g} \mathrm{L}^{-1}$ ) category except for 16 reservoirs which come under meso-eutrophic category (TP $<30 \mu \mathrm{g} \mathrm{L}^{-1}$ ) (Table 3). This situation clearly shows the trophic shift of Sri Lankan reservoirs from meso-eutrophic to eutrophic or hypereutrophic conditions since 1999 (Yatigammana and Cumming 2016). This may be due to the cultural eutrophication prevailing in the country. Although the climatic region does not appear to play a role in the determination of the trophic level of Sri Lankan reservoirs, there may be some seasonal changes where water level fluctuations occur due to rainfall variations. During this study, extensive limnological analysis of the Iranamadu Tank revealed the highest total phosphorus (TP) recorded among all the reservoirs studied. This clearly indicates the effect of intense anthropogenic pressure on the reservoir water quality especially during the civil war.

Sri Lankan reservoirs are categorized as $\mathrm{P}$ limited systems (Yatigammana and Cumming 2016) which is consistent with the findings of Schiemer (1983) and Silva and Schiemer (2000). According to Sakamoto (1966), lakes can be classified as N limited if the TN:TP ratio is $<13$ and as P limited, if the ratio is $>17$. According to our study wet zone reservoirs show $\mathrm{P}$ limited conditions $\left(\mathrm{NO}_{3}{ }^{-}\right.$: $\mathrm{TP}>$ 16). Conversely Intermediate and dry zone reservoirs show $\mathrm{N}$ limited conditions $\left(\mathrm{NO}_{3}{ }^{-}\right.$: $\mathrm{TP}<$ 17). However, as we measured only $\mathrm{NO}_{3}{ }^{-}$as the only $\mathrm{N}$ component, the ratio we obtained is only a rough estimation. The highest mean value of nitrate- $\mathrm{N}$ in the wet zone can be attributed to the high surface runoff which carries excess chemical fertilizers and animal waste due to year-round rainfall prevailing in the wet zone (Senanayake and Yatigammana 2017). The highest TDS and electrical conductivity in the dry zone reservoirs may be a reflection of the nature of the precipitation and the resulting concentration of ions by evapotranspiration and evapoconcentration (MaddumaBandara et al., 2010; Yatigammana et al., 2013). pH and alkalinity data of our survey suggest that Sri Lankan water bodies are near neutral and slightly alkaline.

\section{Correlation between phytoplankton distribution and environmental factors}

According to Multivariate statistics (CCA) during the study provides convincing evidence of the influence of physico-chemical variables on the abundance and distribution of Cyanobacteria and Dinoflagellata in reservoirs of Sri Lanka. It reveals that Secchi depth and area of water spread are the most influential factors determining the distribution patterns of reservoir phytoplankton dominant in Sri Lanka. Anthropogenic pressure and different land use patterns in the catchment of reservoirs have a significant effect on the Secchi depth (water clarity) while flushing rates and wave or wind actions may have some effect on area of water spread. 
Temperature and nutrients such as total phosphorus and $\mathrm{NO}_{3}{ }^{-}$also appear to be important explanatory factors (Sethunga and Pathmalal 2010). According to Senanayake and Yatigammana (2017), the environmental conditions which help distinguish the species distribution includes temperature, conductivity and related variables. Hence it can be suggested that in addition to hydrochemical variables, the physical characteristics of the reservoir influence the phytoplankton community composition and dominance in Sri Lankan reservoirs.

\section{CONCLUSIONS}

Most of the Sri Lankan reservoirs appear to have a risk of eutrophication leading to contamination with cyanobacteria and the situation is more prominent in the Dry Zone. Secchi depth and area of water spread are the most important environmental factors determining the distribution of cyanobacteria and dinoflagellates in Sri Lankan reservoirs.

\section{ACKNOWLEDGMENTS}

Financial assistance from the University of Peradeniya (Research Grant No. RG/2014/42/S) and facilities provided by the Department of Zoology, Faculty of Science, University of Peradeniya, Sri Lanka are acknowledged.

\section{REFERENCES}

Abeywickrama, B. A. 1979. The Genera of the Freshwater Algae of Sri Lanka. Part 1 UNESCO Man and the Biosphere National Committee for Sri Lanka, National Science Council Sri Lanka, Colombo. 103 p.

Akbay, N., N. Anul, S. Yerti, S. Soyupak \& C. Yurteri 1999. Seasonal distribution of large phytoplankton in Keban dam reservoir. Plankton Research 21(4): 771-787. https://doi.org/10.1093/plankt/21.4.771

Alster, A., R.N. Kaplan-Levy, A. Sukenik \& T. Zohary 2010. Morphology and phylogeny of a non-toxic invasive Cylindrospermopsis raciborskii from a Mediterranean Lake. Hydrobiologia 639: 115-128. https://doi. org/10.1007/s10750-009-0044-y

Anon. 1998. Fish kills in Parakrama Samudra. Sri Lanka Association for Fisheries and Aquatic Resources, Newsletter 1.
APHA 1992. Standard Methods for the Examination of Water and Wastewater. $18^{\text {th }}$ Edition, American Public Health Association, Washington, 9-45 p

Arumugam, S. 1969. Water Resources of Ceylon: Its Utilization and Development. Water Resources Board, Colombo, 415 p.

Bellinger, E.G. \& D.C. Sigee 2010. Freshwater Algae: Identification and Use as Bioindicators. John Wiley \& Sons Ltd., New York, 284 p.

Bouvy, M., N. Ba, S. Ka, S. Sane, M. Pagano \& R. Arfi 2006. Phytoplankton community structure and species assemblage succession in a shallow tropical lake (Lake Guiers, Senegal). Aquatic Microbial Ecology 45: 147-161. https://doi.org/10.3354/ame045147

Briand, J.F., C. Leboulanger, J.F. Humbert, C. Bernard \& P. Dufour 2004. Cylindrospermopsis raciborskii (Cyanobacteria) invasion at midlatitudes: selection, wide physiological tolerance, or global warming? Journal of Phycology 40: 231238.https://doi.org/10.1111/j.1529-8817. 2004.03118.x

Bruno, S.F. \& J.J.A. McLaughlin 1977. The nutrition of the freshwater dinoflagellate Ceratium hirundinella. Journal of Protozoology 24: 548-553. https://doi.org/10.1111/j.15507408.1977.tb0 1012.x

Bryant, D.A. (ed.) 1994. The Molecular Biology of Cynaobacteria. Kluwer Academic Publishers, Dordrecht, Boston, London.

Caraco, N.F \& R. Miller 1998. Effects of $\mathrm{CO}_{2}$ on competition between a cyanobacterium and eukaryotic phytoplankton. Canadian Journal of Fisheries and Aquatic Sciences 55: 54-62. https://doi.org/10.1139/f97-202

Cavanagh, N., R.N. Nordin \& P.D. Warrington 1997. Freshwater Biological Sampling Manual. B.C. Ministry of Environment and Resource Information Standards Committee, Victoria, B.C.

Chapman, A.D. \& C.L. Schelske 1997. Recent appearance of Cylindrospermopsis (Cyanobacteria) in five hypereutrophic Florida lakes. Journal of Phycology 33: 191-195. https://doi.org/10.1111/j.0022-3646.1997.001 91.x

Codd, G.A. \& S.G. Bell 1996. The Occurrence and Fate of Blue-green Algae in Freshwaters. R \& D 


\section{P.A.A.P.K. Senanayake et al}

Report 29, National Rivers Authority, London, $30 \mathrm{p}$.

Cronberg, G. \& H. Annadotter 2006. Manual on Aquatic Cyanobacteria. A Photo Guide and Synopsis of Their Toxicology. Issha \& Unesco, Copenhagen, $106 \mathrm{p}$.

Elliott, J.A., A.E. Irish \& C.S. Reynolds 2002. Predicting the spatial dominance of phytoplankton in light limited and incompletely mixed eutrophic water column using the PROTECH model. Freshwater Biology 47: 433440. https://doi.org/ 10.1046/j.13652427.2002.00813.x

Fabbro, L.D. \& L.J. Duivenvoorden 1996. Profile of a bloom of the cyanobacterium Cylindrospermopsis raciborskii (Woloszynska) Seenaya and Subba Raju in the Fitzroy River in tropical central Queensland. Marine and Freshwater Research 47: 685-694. https://doi.org/10.1071/MF9960685

Fastner, J., J. Rucker, A. Stuken, K. Preußel, B. Nixdorf, I. Chorus, A. Kohler \& C. Wiedner 2007. Occurrence of the cyanobacterial toxin cylindrospermopsin in northeast Germany. Environmental Toxicology 22: 26-32. https://doi.org/10.1002/tox.20230

Giaramida, L., M.M. Pathmalal, E. Chritine, B. Singh \& L.A. Lawton 2013. Bacterial communities' response to microcystins exposure and nutrient availability: Linking degradation capacity to community structure. International Biodeterioration and Biodegradation 84: 111-117. https://doi. org/10.1016/j.ibiod.2012.05.036

Herrgesell, P.L., T.H. Sibley \& A.W. Knight 1976. Some observations on dinoflagellate population density during a bloom in a California reservoir. Limnology and Oceanography 21: 619-624. https://doi.org/10.4319/lo.1976.21.4.0619

Holt, J.R. \& L.A. Pfiester 1981. A survey of auxotrophy in five freshwater dinoflagellates (Pyrrhophyta). Journal of Phycology 17: 415416. https://doi.org/10.1111/j.0022-3646.19 81.00415.x

Horne, A.J., P. Javornicky \& C.R. Goldman 1971. A freshwater red tide on Clear Lake, California. Limnology and Oceanography 16: 684-689. https://doi.org/10.4319/lo.1971.1 6.4.0684

Huisman, J., J. Sharples, J. Stroom, P.M. Visser, W.E.A. Kardinaal, J.M.H. Verspagen \& B. Sommeijer 2004. Changes in turbulent mixing shift competition for light between phytoplankton species. Ecology 85: 2960-2970. https://doi.org/10.1890/03-0763

Huszar, V., C. Kruk \& N. Caracao 2003. Steadystate assemblages of phytoplankton in four temperate lakes (NE USA). Hydrobiologia 502: 97-109. https://doi.org/10.1007/978-94-0172666-5_9

Idroos, F.S. \& M.M. Pathmalal 2018. Bioremediation of Microcystins by two native bacteria: Bacillus cereus and Rahnella aquatilis. Asian Journal of Microbiology, Biotechnology and Environnemental Sciences 20(3): 24-32. http://science.sjp.ac.lk/zoo/wp-content/uplo ads/sites/20/2018/05/Idroos-and-PathmalalPublished-1.pdf

Idroos, F.S., I.U. Hettiarachchi \& M.M. Pathmalal 2014. Optimization of a standard Method for enumeration of total cell counts of colonial Microcystis aeroginosa in environmental samples from Boralasgamuwa lake. Vidyodaya Journal of Science 18: 45-54. https://doi.org/10.31357/fesympo.v18i 0.1902

Indika U.H. \& M.M. Pathmalal 2014. Cyanobacterial cell density and intracellular Microcystin-LR levels in drinking/ irrigation reservoirs in Anuradhapura, Sri Lanka. In: Environment and Natural Resources. Conference Proceedings 306-310.

Istvánovics, V., H.M. Shafik, M. Présing \& S. Juhos 2000. Growth and phosphate uptake kinetics of the cyanobacterium Cylindrospermopsis raciborskii (Cyanophyceae) in throughflow cultures. Freshwater Biology 43: 257-275. https://doi.org/10.1046/j.1365-2427.2000.0 0549. $x$

Jayatissa, L.P., L.A. Lawton, R. Karunatilake \& B.J.P.A. Cornish 1998. Seasonal variations in the toxicity in two perennial blooms of cyanobacteria in Sri Lanka. In: Toxic Cyanobacteria. Conference Proceedings, p. 80.

Jones, G.J. 1994. Cyanobacterial Research in Australia. Australian Journal of Marine Freshwater Research 45: 731-915.

Kokociński, M., K. Stefaniak, J. MankiewiczBoczek, K. Izydorczyk \& J. Soininen 2010. The ecology of the invasive cyanobacterium Cylindrospermopsis raciborskii (Nostocales, Cyanophyta) in two hypereutrophic lakes dominated by Planktothrix agardhii (Oscillatoriales, Cyanophyta). European Journal 
of Phycology 45(4): 365-374. https://doi.org/10.1080/09670262.2010.492916

Kokociński, M. \& J. Soininen 2012. Environmental factors related to the occurrence of Cylindrospermopsis raciborskii (Nostocales, Cyanophyta) at the North-Eastern limit of its geographical range. European Journal of Phycology 47(1): 12-21. https://doi.org/10.1080/09670262.2011.645216

Lagos, N., H. Onodera, P.A. Zagatto, D. Andrinolo, S. Azevedo \& Y. Oshima 1999. The first evidence of paralytic shellfish toxins in the freshwater cyanobacterium Cylindrospermopsis raciborskii, isolated from Brazil. Toxicon 37: 1359-1373. https://doi.or g/10.1016/S00410101(99)00080-X

Laing, T.E. and J.P. Smol 2003. Late Holocene environmental changes inferred from diatoms in a lake on the western Taimyr Peninsula, northern Russia. Journal of Paleolimnology 30: 231-247. https://doi.org/10.1023/A: 1025561905506

Lindström, K. 1992. Ceratium in Lake Erken: vertical distribution, migration and form variation. Nordic Journal of Botany 12: 541-556. https://doi.org/10.1111/j.1756-1051.199 2.tb01833.x

Lotter, A., H.J.B. Birks, W. Hofmann \& A. Marchetto 1997. Modern diatom, cladocera, chironomid, and chrysophyte cyst assemblages as quantitative indicators for the reconstruction of past environmental conditions in the Alps. Journal of Paleolimnology 18: 395-420. https://doi.org /10.1023/A:1007982008956

Madduma Bandara, C.M., S.K. Yatigammana \& G. Paranavithana 2010. Scientific validation of some traditional land and water management practices under village tank cascade system. Economic Review 36 (1, 2): 21-28.

McQueen, D.J. \& D.R.S. Lean 1987. Influence of water temperature and nitrogen to phosphorus ratios on the dominance of blue-green algae in Lake St. George, Ontario. Canadian Journal of Fisheries and Aquatic Sciences 44: 598-604. https://doi.org/10.1139/f87-073

Moisander, P. H., L.A. Cheshire, J. Braddy, E. Calandrino, H. Hoffman, M.F. Piehler \& H.W. Paerl 2012. Facultative diazotrophy increases Cylindrospermopsis raciborskii competitiveness under fluctuating nitrogen availability. Federation of European Microbiological Societies $\quad 79$ : $800-811$. https://doi.org/10.1111/j.1574-

6941.2011.01264.x

Morabito, G., D. Ruggiu \& P. Panzani 2002. Recent dynamics (1995-1999) of the phytoplankton assemblages in Lago Maggiore as a basic tool for defining association patterns in the Italian deep lakes. Journal of Limnology 61(1): 129-145. https://doi.org/10.4081/jlimnol.2002.129

Moustaka-Gouni, M., K.A. Kormas, E. Vardaka, M. Katsiapi \& S. Gkelis 2009. Raphidiopsis mediterranea Skuja represents nonheterocystous life-cycle stages of Cylindrospermopsis raciborskii (Woloszynska) Seenayya et Subba Raju in Lake Kastoria (Greece), its type locality: evidence by morphological and phylogenetic analysis. Harmful Algae 8: 864-872. https://doi.org/10.1016/j.hal.2009.04.003

Moustaka-Gouni, M., E. Vardaka \& E. Tryfon 2006. Phytoplankton species succession in a shallow Mediterranean lake (L. Kastoria, Greece): steady-state dominance of Limnothrix redekei, Microcystis aeruginosa and Cylindrospermopsis raciborskii. Hydrobiologia 575: 129-140. https://doi.org/10.1007/s10750-006-0360-4

Munnawar, M. 1970. Limnological studies in fresh water ponds of Hyderabad, India. II. The biotope. Hydrobiologia 35:127-162. https://doi.org/10.1007/BF00143305

Munnawar, M. 1972. Ecological studies of Euglenaceae in certain polluted and unpolluted environments. Hydrobiologia 39: 307-320 https://doi.org/10.1007/BF00046647

Mur, L.R., H. Schreurs \& P. Visser. 1993. How to control undesirable cyanobacterial dominance. In: Strategies for Lake Ecosystems Beyond 2000 (G. Giussani and C. Callieri eds), pp. 565-569. Conference Proceedings.

Niesel, V., E. Hoehn, R. Sudbrack, H. Willmitzer \& I. Chorus 2007. The occurrence of the Dinophyte species Gymnodinium uberrimum and Peridinium willei in German reservoirs. Journal of Plankton Research 29(4): 347-357. https://doi.org/10.1093/plankt/fbm017

Nishii, K., S. Nakano, M. Tamada, M.M. Pathmalal, Y. Nishibe \& K. Zen ichiro 2001. Microbial decomposition of dissolved organic matter in a hypereutrophic pond. Limnology 2: 207-212. https://doi.org/10.1007/s10201-001-8037-1

Olrik, K. 1992. Ecology of Peridinium willei and $P$. volzii (Dinophyceae) in Danish lakes. Nordic 


\section{P.A.A.P.K. Senanayake et al}

Journal of Botany 12: 557-568. https://doi.org/10.1111/j.1756-1051.1992.tb 01834.x

Padisa'k, J., L. Crossetti \& L. Naselli-Flores 2009. Use and misuse in the application of the phytoplankton functional classification: a critical review with updates. Hydrobiologia 621: 1 19 . https://doi.org/10.1007/s10750-008-9645-0

Paerl, H.W. \& J. Huisman 2008. Blooms Like It Hot. Science 320: 57-58. https://doi.org/ 10.1126/science. 1155398

Pathmalal, M.M., K. Zen `ichiro \& N. Shin-ichi 2001. Dynamics of cyanophages-like particles and algicidal bacteria causing Microcytis aeruginosa mortality. Limnology 2: 73-78. https://doi.org/10.1007/s1020101 70002

Pathmalal, M.M., K. Zen ichiro, N. Shin-ichi \& N. Yuichiro 2002. Effect of heterotrophic nanoflagellates on the loss of virus-like particles in pond water. Ecological Research 17: 473479 . https://doi.org/10.1046/j.14401703.2002.00504.x

Pathmalal, M.M., K. Zen ichiro \& N. Shin-ichi 1999. Seasonal changes in densities of cyanophage infectious to Microcytis aeruginosa in a hypereutrophic pond. Hydrobiologia 411: 211-216. https://doi.org/10.1023/A:1003868803832

Pathmalal, M.M. \& S. Piyasiri 1995. The chlorophyll-a content, species composition and population structure of phytoplankton in Randenigala reservoir in Sri Lanka. Vidyodaya Journal of Science 5: 29-41.

Pathmalal, M.M. \& S.N. Premetilake 2011. Occurrence of heterotrophic bacteria causing lysis of M. aeruginosa in Beira Lake, Sri Lanka. Vidyodaya Journal of Science 16: 31-56.

Pathmalal, M.M., K. Zen ichiro \& N. Shin-ichi 2000. Algicidal effect of the bacterium Alcaigenes denitrificans on Microcystis spp. Aquatic Microbial Ecology 22: 111-117.

Pathmalal, M.M. 2009. Seasonal changes in the abundance of biological agents killing Microcystis aeruginosa in a hypereutrophic pond. Vidyodaya Journal of Science 14(2): 85101.

Pathmalal, M.M., E. Chritine \& A.L. Linda 2010. Bacterial degradation of microcystin. In: Interdisciplinary Studies on Environmental Chemistry-Biological Responses to Contaminants (N. Hamamura, S. Suzuki, S.
Mendo \& C.M. Barroso eds), pp 97-104. TERRAPUB: Tokyo.

Pathmalal M.M., E. Chritine, K.S. Brajesh \& A.L. Linda 2009. Isolation and identification novel microcystin degrading bacteria. Applied and Environmental Microbiology 75(21): 69246928.

Peerapornpisal, Y., W. Sonthichai, T. Somdee, P. Mulsin \& E. Rott 1999. Water quality and phytoplankton in the Mae Kuang Udomtara Reservoir, Chiang Mai, Thailand. Chiang Mai Journal of Science 26(1): 25-43. https://doi.org/10.2520/myco1975.1999.Suppl2 -257'

Perera, M.B.U. S.K. Yatigammana \& S.A. Kulasooriya 2012. Prevalence of toxigenic cyanobacteria in different climatic zones of Sri Lanka. In: International symposium on Water Quality and Human Health: Challenges Ahead (O.A. Illeperuma ed), Conference Proceedings 31-32 p. Postgraduate Institute of Science, University of Peradeniya, Sri Lanka.

Perera, N. and S. Piyasiri 1998. Species composition and population dynamics of the phytoplankton community in Kotmale Reservoir. Journal of the National Science Foundation of Sri Lanka 26(4): 293-309.

Phillips, G., A. Lyche-Solheim, B. Skjelbred, U. Mischke, S. Drakare, G. Free, M. Ja“rvinen, C. de Hoyos, G. Morabito, S. Poikane\&L. Carvalho 2012. A phytoplankton trophic index to assess the status of lakes for the Water Framework Directive. Hydrobiologia 704: 75-95. https://doi.org/10.1007/s10750-012-1390-8

Pizzolon, L., B. Tracanna, C. Prósperi \& J. M. Guerrero 1999. Cyanobacterial blooms in Argentinean inland waters. Lakes \& Reservoirs 4: 101-105. https://doi.ozrg/ 10.1046/j.14401770.1999.000 85.x

Pollingher, U. 1988. Freshwater armored dinoflagellates: growth, reproduction strategies, and population dynamics. In: Growth and Reproductive Strategies of Freshwater Phytoplankton (C.D. Sandgren ed). pp.134-174. Cambridge University Press, Cambridge.

Pollingher, U. \&C. Serruya, C. 1976. Phased division of Peridinium cinctum fa. westii and the development of the bloom in Lake Kinneret (Israel). Journal of Phycology 12: 162170.https://doi.org/10.1111/j.15298817. 1976.tb00494.x 
Reynolds, C.S. \& A.E. Walsby 1975. Water Blooms. Biological Reviews 50: 437-481. https://doi.org/10.1111/j.1469185X.1975.tb01060.x

Reynolds, C.S. 1984. The Ecology of Freshwater Phytoplankton. Cambridge University Press, Cambridge, $384 \mathrm{p}$.

Robarts, R. S. 1985. Hypertrophy, a consequence of development. International Journal of Environmental Studies 12: 72-89. https://doi.org/10.1080/00207238508710222

Rott, E. 1983. A contribution to the phytoplankton species composition of Parakrama Samudra, an ancient man-made lake in Sri Lanka. In: Limnology of Parakrama Samudra - Sri Lanka: A case study of an ancient man-made lake in the tropics (F. Schiemer ed), pp. 209-226. The Hague,

Netherlands. https://doi.org/10.1007/978-94-009-7281-0_20

Rott, E. \& R. Lenzenweger 1994. Rare and interesting plankton algae from Sri Lankan reservoirs. Biologia 49: 479-500.

Sakamoto, M. 1966. Primary production by phytoplankton community in some Japanese lakes and its dependence on lake depth. Archive fur Hydrobiologiae 62: 1-28.

Schiemer, F. 1983. The limnology of Parakrama Samudra, Sri Lanka. W. Junk Publishers, The Hague-Boston-London, 233 p. https://doi.org/ 10.1007/978-94-009-7281-0

Schindler, D.W. 1977. Evolution of Phosphorus Limitation in Lakes. Science 195: 260-262. https://doi.org/10.1126/science.195.4275.260

Schreurs, H. 1992. Cyanobacterial dominance. Relations to eutrophication and lake morphology. Doctoral Thesis, University of Amsterdam. 198 p.

Senanayake, P.A.A.P.K. \& S.K. Yatigammana 2017. Quantitative observations of Cyanobacteria and Dinoflagellata in reservoirs of Sri Lanka. Ceylon Journal of Science 46(4): 5568. https://doi.org/10.4038/cjs.v46i4.7468

Sethunga S. \& Pathmalal M.M. 2010. Nuisance algae in water supply projects in Sri Lanka. In: International Conference on Sustainable Built Environment, pp. 62-70, ICSBE- 2010 Conference Proceedings, Kandy, Sri Lanka.

Shafik, H. M., S. Herodek, M. Presing \& L. Voros 2001. Factors effecting growth and cell composition of cyanoprokaryote Cylindrospermopsis raciborskii (Woloszynska)
Sheenayya et Subba Raju. Algological Studies 102: 75-93. https:// doi.org/10.1127/algol_stud/103/2001/75

Shin-ichi, N., I. Nobuyoshi, M.M. Pathmalal \& K. Zen ichiro 1998. Trophic roles of heterotrophic nanoflagellates and cilitaes among planktonic organisms in a hypereutrophic pond. Aquatic Microbial Ecology 16: 153-161. https://doi.org/10.335 4/ame016153

Shin-ichi, N., M.M. Pathmalal, N. Yuichiro \& K. Zen ichiro 2001. Trophic linkage among heterotrophic nanoflagellates, ciliates and metazoan zooplankton in a hypereutrophic pond. Aquatic Microbial Ecololgy 25: 259-270. https://doi.org/10.3354/ame025259

Silva, E.I.L. \& G.A.R.K. Gamlath 2000. Catchment characteristics and water quality of three reservoirs (Victoria, Minneriya and Udawalawe) in Sri Lanka. Sri Lanka Journal of Aquatic Sciences 5: 55-73.

Silva, E.I.L. \& F. Schiemer 2000. Hydraulic changes of three reservoirs (Minneriya, Udawalawa and Victoria) in Sri Lanka. Sri Lanka Journal of Aquatic Sciences 5: 75-86.

Silva, E.I.L. \& F. Schiemer 2001. Human factor: Fourth dimension of the Limnology in tropics. In: Reservoirs and culture-based fisheries: Biology and Management. (S.S. De Silva ed), pp. 111-125, ACIAR Proceedings 98, Australian Centre for Agricultural Research, Canberra.

Silva, E.I.L. \& M.J.S. Wijeyaratne 1999. The occurrence of Cyanobacteria in the reservoirs of the Mahaweli river basin in Sri Lanka. Sri Lanka Journal of Aquatic Sciences 4: 51-60.

Silva, E.I.L., E. Rott, I. Thumpela, N. Athukorala \& E.N.S. Silva 2013. Species composition and relative dominance of reservoir phytoplankton in Sri Lanka: indicators of environmental quality. International Journal of Biological Sciences and Engineering 4(4): 92-102.

Smith, V.H. 1983. Low nitrogen to phosphorus ratios favors dominance by blue-green algae in lake phytoplankton. Science 221: 669-671. https://doi.org/10.1126/science.221.4611.669

Smith, V. H., E. Willén \& B. Karlsson 1987. Predicting the summer peak biomass of four species of blue-green algae (Cyanophyta/Cyanobacteria) in Swedish lakes. Journal of the American Water Resources Association 23: 397-402. https:// doi.org/10.1111/j.1752-1688.1987.tb00818.x 


\section{P.A.A.P.K. Senanayake et al}

Stüken, A., J. RüCker, T. Endrulat, K. Preussel, M. Hemm, B. Nixdorf, U. Karsten \& C. Wiedner 2006. Distribution of three alien cyanobacterial species (Nostocales) in northeast Germany: Cylindrospermopsis raciborskii, Anabaena bergii and Aphanizomenon aphanizomenoides. Phycologia 45: 696-703. https://doi.org/ 10.2216/05-58.1

Valerio, E., P. Pereira, M.L. Saker, S. Franca \& R. Tenreiro 2005. Molecular characterization of Cylindrospermopsis raciborskii strains isolated from Portuguese freshwaters. Harmful Algae 4: 1044-1052. https://doi.org/10.1016/j.hal.2005.03.002

Van dam, H., A. Mertens \& J. Sinkeldam 1994. A coded checklist and ecological indicator values of freshwater diatoms from the Netherlands. Netherland Journal of Aquatic Ecology 28: 117 - 133. https://doi.org /10.1007/BF02334251

Visser, M.E. \& C. Both 2005. Shifts in phenology due to global climate change: the need for a yardstick. Proceedings of the Royal Society B. Biological Sciences 272: 2561-2569. https://doi.org/10.1098/rspb.2005.3356

Vyverman, W. 1996. The Indo-Malaysian NorthAustralian phycogeographical region revised. Hydrobiologia 336: 107-120. https://doi. org/10.1007/BF00010824

Wang, Y.W., J. Zhao, J.H. Li, S.S. Li, L. H. Zhang \& M. Wu 2011. Effects of calcium levels on colonial aggregation and buoyancy of Microcystis aeruginosa. Current Microbiology 62(2): 679- 683. https:// doi. org/10.1007/s00284-010-9762-7

Watanabe, T. \& H. Shiraishi 1983. Outbreak mechanism of freshwater red tide caused by the abundant occurrence of Peridinium bipesf. occulatum in Kazaya Reservoir. Research and Reports in Environmental Biology, Nara Women's University 1: 5-8.

Watanabe, T. \& M. Takada 1983. Outbreak mechanism of freshwater red tide caused by the abundant occurrence of Peridinium cinctum $f$. westii in Kazaya Reservoir. Research and Reports in Environmental Biology, Nara Women's University 1: 9-14.

Weckström, J., A. Korhola \&T. Blom, T. 1997. Diatoms as quantitative indicators of $\mathrm{pH}$ and water temperature in subarctic Fennoscandian lakes. Hydrobiologia 347: 171-84. https://doi.org/10.1023/A:1003091923476

Williams, D.B. 1971. The occurrence of dinoflagellates in marine sediments. In: Micropalaeontology of the Oceans, (B.M. Funnel and W.R. Riedel eds), pp 231-243. Cambridge University Press, Cambridge.

Yatigammana, S. K. \& M.B.U. Perera 2017. Distribution of Cylindrospermopsis raciborskii (Cyanobacteria) in Sri Lanka. Ceylon Journal of Science 46(3): 65-80 https://doi.org/10.4038/cjs.v46i3.7444

Yatigammana, S., B. Perera \& N. Atukorala 2013. Seasonal Water Quality Changes in Reservoirs in Different Climatic Regions of Sri Lanka. Journal of Ecotechnology Research 17(1): 17- 22.

Yatigammana, S.K. \& B.F. Cumming 2016. Physical and chemical characteristics of ancient and recent reservoirs of Sri Lanka. Fundamental and Applied Limnology 188(3): 249 - 263. https://doi.org/10.1127/fal/2016/0920

Yatigammana, S.K., O.A. Ileperuma \& M.B.U. Perera 2011. Water pollution due to a harmful algal bloom: A preliminary study from two drinking water reservoirs in Kandy, Sri Lanka. Journal of the National Science Foundation 39(1): 91-94. https://doi.org/10.4038/jnsfsr.v 39i1.2930

Yuichiro, N., M.M. Pathmalal, K. Zen'ichiro \& N. Shin-ichi 2004. Trophic coupling of testate amoeba and Microcystis species in a hypereutrophic pond. Limnology 5: 71-76. https://doi.org/10.1007/s10201-004-0114-9 